\title{
Adoptive T-cell immunotherapy from third-party donors: characterization of donors and set up of a T-cell donor registry
}

\author{
Britta Eiz-Vesper $^{1 *}$, Britta Maecker-Kolhoff ${ }^{2}$ and Rainer Blasczyk ${ }^{1}$ \\ ${ }^{1}$ Institute for Transfusion Medicine, Hannover Medical School, Hannover, Germany \\ 2 Department of Pediatric Hematology and Oncology, Hannover Medical School, Hannover, Germany
}

Edited by:

Hermann Einsele, University

Hospital Würzburg, Germany

Reviewed by:

Luiza Guilherme, University of

São Paulo, Brazil

Reem Al-Daccak, Institut National

de la Santé et de la Recherche

Medicale, France

*Correspondence:

Britta Eiz-Vesper, Institute for Transfusion Medicine,

Hannover Medical School,

Carl-Neuberg-Strasse 1,

Hannover, Germany.

e-mail: eiz-vesper.britta@

mh-hannover.de
Infection with and reactivation of human cytomegalovirus (CMV), Epstein-Barr virus (EBV), and adenovirus (ADV) are frequent and severe complications in immunocompromised recipients after hematopoietic stem cell transplantation (HSCT) or solid organ transplantation (SOT). These serious adverse events are associated with significant morbidity and mortality. Donor lymphocyte infusions (DLIs) are often used to treat both viral infections and leukemia relapses after transplantation but are associated with potentially life-threatening graft-versus-host disease (GvHD). Adoptive immunotherapy with virus-specific cytotoxic effector T cells (CTLs) derived from seropositive donors can rapidly reconstitute antiviral immunity after HSCT and organ transplantation. Therefore, it can effectively prevent the clinical manifestation of these viruses with no significant acute toxicity or increased risk of GvHD. In conditions, where patients receiving an allogeneic cord blood (CB) transplant or a transplant from a virus-seronegative donor and since donor blood is generally not available for solid organ recipients, allogeneic third party T-cell donors would offer an alternative option. Recent studies showed that during granulocyte colony-stimulating factor (G-CSF) mobilization, the functional activity of antiviral memory $T$ cells is impaired for a long period. This finding suggests that even stem cell donors may not be the best source of $T$ cells. Under these circumstances, partially human leukocyte antigen (HLA)-matched virus-specific CTLs from healthy seropositive individuals may be a promising option. Therefore, frequency assessments of virus-specific memory $T$ cells in HLA-typed healthy donors as well as in HSCT/SOT donors using a high throughput T-cell assay were performed over a period of 4 years at Hannover Medical School. This chapter will address the relevance and potential of a third-party T-cell donor registry and will discuss its clinical implication for adoptive T-cell immunotherapy.

Keywords: adoptive immunotherapy, T-cell therapy, antiviral T lymphocytes, cytomegalovirus, Epstein-Barr virus, adenovirus

\section{INTRODUCTION}

Hematopoietic stem cell transplantation (HSCT) is used to cure many malignant, benign and genetic disorders of the bone marrow, solid tumors, immunodeficiencies, metabolic, and autoimmune disorders (Ljungman et al., 2010). HSCT is generally performed after administration of sublethal doses of chemotherapy or chemoradiotherapy to achieve myeloablation, immunosuppression and eradication of abnormal cells. Intensive immunosuppressive therapy for prevention of graft rejection and graft-versus-host disease (GvHD) and for treatment of GvHD puts the patients at risk of opportunistic infections due to an ablated or severely compromised T-cell immune response. Such invasive conditioning procedures lead to a lack of immunological competence, which results mainly in a decrease in the number of CD3+ T lymphocytes in the patient's peripheral blood. Lymphopenia increases the patient's risk of de novo infection or reactivation of a latent virus. This mainly occurs during the early post-transplantation period and usually leads to a disseminated disease. The immune reconstitution period following HSCT (as long as 3-6 months) is therefore accompanied by a high incidence of infections with various pathogens that are normally controlled by T-cell immunity.

\section{ROLE OF T CELLS IN TRANSPLANTATION}

In allogeneic HSCT, the presence of a defined number of donorderived $\mathrm{T}$ cells in the stem cell graft may prevent graft failures, infections or reactions caused by different pathogens (graftversus-infection effect, GvI) as well as disease relapses (graftversus-leukemia/graft-versus-tumor effect, $\mathrm{GvL} / \mathrm{GvT}$ ). On the other hand, an excessive number of $\mathrm{T}$ cells may increase the risk of developing GvHD. Major complications of stem cell and organ transplantation, such as graft rejection and GvHD, are countered by suppressing the host immune system via chemotherapy and radiation, immunosuppressive drugs, or conditioning regimens such as in vivo or in vitro T-cell depletion (Gooley et al., 2010). While immunocompromised, the patient is rendered susceptible 
to a number of viral infections mainly caused by endogenous herpes viruses like cytomegalovirus (CMV) and Epstein-Barr virus (EBV) and by lytic agents such as adenovirus (ADV). Infections by several other viruses such as polyoma virus BK (BKV) and human herpesvirus 6 (HHV-6) as well as by invasive fungal pathogens such as Aspergillus are also reported to cause significant complications after stem cell and solid organ transplantation (SOT) (Marr et al., 2002; Garcia-Vidal et al., 2008; Pappas et al., 2010; Amir et al., 2011; Breuer et al., 2012).

\section{VIRAL COMPLICATIONS AFTER ALLOGENEIC STEM CELL TRANSPLANTATION AND ORGAN TRANSPLANTATION CMV INFECTION}

Human CMV is a persistent $\beta$-herpesvirus that infects most healthy individuals during the first years of life (Khan, 2007). Healthy CMV-seropositive individuals have a high number of CMV-specific CD8+ and CD4+ T lymphocytes, which are essential to control viral reactivation without clinical symptoms (Rauser et al., 2004). Immunocompromised CMV-seropositive patients $(\mathrm{R}+)$ receiving a graft from a seronegative donor $(\mathrm{D}-)$ have a high risk of CMV disease (Zhou et al., 2009; Borchers et al., 2011; Ugarte-Torres et al., 2011). Additionally, it was reported that CMV reactivation developed in $96 \%$ of $\mathrm{D}+\mathrm{R}+$ patients but in less than $50 \%$ of $\mathrm{D}+\mathrm{R}-$ patients (Lilleri et al., 2008, 2012). Reactivation of CMV results in significant morbidity and mortality; clinical manifestations include interstitial pneumonitis, gastroenteritis, fever, hepatitis, encephalitis, and retinitis (Einsele et al., 2008; Fujita et al., 2008a,b). While ganciclovir, valganciclovir, foscarnet, and cidofovir may help to prevent or treat CMV infection, they are associated with late-onset disease and serious side-effects, such as nephrotoxicity, myelosuppression, and impaired immune reconstitution, leading to an increase in invasive fungal infections and bacterial sepsis (Broers et al., 2000; Battiwalla et al., 2007; Fujita et al., 2008a,b; Boeckh and Ljungman, 2009). Furthermore, these drugs are often ineffective due to primary or secondary resistance, and patients still develop CMV disease in spite of antiviral treatment (Einsele et al., 2000; Mori et al., 2000; Fuji et al., 2011). Hence, cellular immunity is important for the control of CMV infection, and CMV-specific $\mathrm{CD} 8+$ and CD4+ $\mathrm{T}$ cells are essential for efficient immune protection after both primary activation and reactivation of latent CMV disease (Fujita et al., 2008a,b; Feuchtinger et al., 2010; Fuji et al., 2011).

\section{EBV INFECTION}

EBV-associated post-transplant lymphoproliferative disease (PTLD) occurring after HSCT or SOT is a potentially lifethreatening condition (Cohen, 2000; Gottschalk et al., 2005). The overall incidence of PTLD after allogeneic HSCT is less than $1 \%$, but was reported to be increased after transplantation with human leukocyte antigen (HLA)-mismatched or T-celldepleted grafts (Landgren et al., 2009). Further risk factors for the development of PTLD include the degree and duration of immunosuppressive treatment and the use of antithymocyte globulin (ATG) with reduced-intensity transplant conditioning (Landgren et al., 2009; Pidala et al., 2011). PTLD developing after hematopoietic SCT usually results from donor B cells and appears within the first 6-12 months post-transplant, when profound deficiencies of EBV-specific cytotoxic effector T cells (CTLs) (EBV-CTLs) occur (Meij et al., 2003). In SOT, the incidence varies with the type of organ (1-2\% after kidney transplantation and up to $20 \%$ after thoracic organ transplantation) (Trappe et al., 2012). Eighty five percentage of pediatric PTLDs and $60-70 \%$ of adult PTLDs in Europe are EBV-associated. Insufficient EBV-specific T-cell responses have been linked to a higher risk of PTLD development (Guppy et al., 2007). PTLD in SOT recipients usually originates from recipient B cells; however, a significant percentage $(10-15 \%)$ of predominantly early PTLD in kidney or liver graft recipients restricted to the organ graft displays donor origin (Olagne et al., 2011). Treatment includes reduction of immunosuppressive drugs as far as tolerated, immunotherapy (monoclonal antibodies like Rituximab), and cytotoxic chemotherapy. Preemptive therapy with CD20 monoclonal antibodies (Rituximab) has been attempted and may control EBV-associated lymphoproliferation (Kuehnle et al., 2000; van Esser et al., 2002; Trappe et al., 2012). Treatment is often complicated by side effects, and severe complications are foreseeable in patients with pre-existing organ dysfunction. Second line treatment options are scarce and have not been tested in clinical studies. Adoptive T-cell therapy using EBV-CTLs has been successfully employed for prophylaxis and treatment of PTLD in high-risk patients (Haque et al., 2007; Heslop et al., 2010; Shen et al., 2011).

\section{ADV INFECTION}

The incidence of ADV infection ranges from 3 to $20 \%$, and is significantly higher in pediatric patients (Feuchtinger et al., 2005; Fowler et al., 2010). Overall ADV-associated mortality ranges from 18 to $26 \%$. ADV infection may involve the respiratory, gastrointestinal and/or urinary tract. The diagnosis of ADV infection can be difficult due to its complexity. The most common cause of adenoviral infection after HSCT is reactivation of a latent virus persisting, for example, in intestinal mucosa. Furthermore, there are reports indicating a more than 4 -fold increased risk of ADV infection in patients with grafts from seropositive donors (Runde et al., 2001; Walls et al., 2003; Fowler et al., 2010). Risk factors underlying this increase are: T cell-depleted grafts (Chakrabarti et al., 2002; Lion et al., 2003), allogeneic graft from matched unrelated donors (MUD) (Ebner et al., 2005), acute GvHD (Bruno et al., 2003), cytotoxic and immunosuppressive therapy (Watcharananan et al., 2010), and lymphocytopenia (Feuchtinger et al., 2008; Watcharananan et al., 2010). Currently, 53 different human serotypes (ADV1 to ADV53) are classified into seven species (A to G). The most prevalent serotypes in transplant patients are ADV 1, 2, 5, 31, and 41. In 49 pediatric patients who received a stem cell transplant at Hannover Medical School (MHH) from 2003 to 2011, sequence analysis revealed ADV species A (1\% ADV18, 20.5\% ADV31), B (4\% ADV3), C (20.5\% ADV1, 32\% ADV2, $4 \%$ ADV6), E ( $8 \%$ ADV4), and F (10\% ADV41) (Mynarek et al., submitted). Incidence of ADV viremia was high (50\%) with mostly asymptomatic patients, who developed only low viral loads. Despite a low ADV-related mortality rate of $0.84 \%$ in this cohort, high peak ADV blood loads were a significant 
and independent risk factor for survival after HSCT. Cidofovir and Ribavirin have been used to treat immunocompromised patients suffering from ADV infection (Lankester et al., 2004; Lindemans et al., 2010). However, these antiviral agents were shown to limit but not clear the infection and are associated with severe side effects. Recent studies indicate that the elimination of ADV is only achieved by recovery of cellular immunity (Feuchtinger et al., 2006). Therefore, the adoptive transfer of antigen-specific $\mathrm{T}$ cells could be an effective and non-toxic alternative strategy.

\section{ADOPTIVE T-CELL THERAPY USING ANTIVIRAL T CELLS}

Although donor lymphocyte infusions (DLIs) can be used after transplantation to treat both viral infections and leukemia relapses, they are associated with potentially life-threatening GvHD (Collins et al., 2000; Choi et al., 2005). The shortcomings of conventional therapies have increased the interest in an immunotherapeutic approach to treat viral disorders. It was recently shown that the adoptive transfer of antiviral cytotoxic T lymphocytes directed against CMV (Einsele et al., 2008; Mackinnon et al., 2008; Brestrich et al., 2009; Feuchtinger et al., 2010; Peggs et al., 2011), EBV (Haque et al., 2010; Heslop et al., 2010; Moosmann et al., 2010; Doubrovina et al., 2012), and ADV (Feuchtinger et al., 2008; Hoffman, 2009; Zandvliet et al., 2010; Qasim et al., 2011) isolated from seropositive donors can rapidly reconstitute antiviral immunity after stem cell and organ transplantation without significant toxicity and with limited increase in GvHD. Infusions of peripheral blood-derived T-lymphocyte lines enriched in multivirus (CMV, EBV, and ADV)-specific $\mathrm{T}$ cells reproducibly controlled infections by all three viruses after allogeneic HSCT and may form the basis of future adoptive immunotherapy trials in patients at risk of multiple infections (Leen et al., 2006; Fujita et al., 2008a,b; Khanna et al., 2011; Zandvliet et al., 2011; Gerdemann et al., 2012).

Although the minimal frequency of antigen-specific $\mathrm{T}$ cells required to mediate an antiviral effect in patients is not known it is likely to vary widely depending on the target antigen and other factors, including quantitative and even more qualitative properties of the effector T cells as well as the host environment. The importance of the host environment to facilitate persistence and function of transferred $\mathrm{T}$ cells has recently been elucidated (Berger et al., 2009).

\section{ADOPTIVE T-CELL THERAPY FOR CMV INFECTION}

The presence of CD8+ and CD4+ antiviral T cells was reported to be essential in controlling viral infection and reactivation by restoring cellular immunity. Since the first promising results began to emerge in the early 1990s (Greenberg et al., 1991; Riddell et al., 1991), different strategies to generate virus-specific T lymphocytes for clinical use have been described. In 1995, Walter and colleagues demonstrated that CMV reactivation after HLAidentical allogeneic HSCT can be prevented by adoptive transfer of CMV-specific cytotoxic T cells, which were generated in vitro from the transplant donor and transferred to the patient (Walter et al., 1995). To be suitable for clinical applications, the cells used for adoptive T-cell transfer must be virus-specific $\mathrm{T}$ cells generated by in vitro induction and expansion from a small number of precursor cells, over a short period of culture, under highly reproducible conditions, and in accordance with good manufacturing practice (GMP). CMV-specific memory T cells are present at high frequencies in the blood of healthy CMV-seropositive donors. Typically, they represent $0.5 \%$ to $4 \%$ of the CD $8+$ T-cell pool and $0.05 \%$ to $1.6 \%$ of the CD $4+\mathrm{T}$ helper (Th) cell pool (Rentenaar et al., 2000; Cwynarski et al., 2001). Most protocols for the generation of virus-specific T cells use peptide-loaded monocytederived dendritic cells (DCs), artificial antigen-presenting cells (aAPCs), or CMV-infected immature dendritic cells as stimulator cells (Sun et al., 1999; Peggs et al., 2001; Carlsson et al., 2003; Oelke et al., 2003; Lozza et al., 2005; Paine et al., 2007, 2010; Lilleri et al., 2008). However, these protocols are difficult to standardize and often laborious to adapt to GMP conditions. Furthermore, previous works have defined CD4+ and/or CD8+ T-cell responses to whole viral lysates, virally infected cells, recombinant proteins, and various HLA-restricted viral peptides.

The majority of studies have focused on the $65 \mathrm{kDa}$ matrix phosphoprotein (pp65, also known as glycoprotein 64 and UL83) and the immediate-early protein 1 (IE1) of CMV as immunodominant targets of CMV-specific T-cell responses (Solache et al., 1999; Elkington et al., 2003; Sylwester et al., 2005). Regarding the induction of antiviral T-cell responses, pp65 has been recognized as a source of immunodominant epitopes that stimulate both CTLs and T helper cells. Most pp65-specific T cells predominantly produce effector cytokines like interferon-gamma (IFN- $\gamma$ ), interleukin-2 (IL-2) and tumor necrosis factor-alpha $(\mathrm{TNF}-\alpha)$. The secretion of these cytokines is used for the detection and enrichment of antiviral T cells (Rauser et al., 2004). HLA class I-restricted peptides derived from CMV pp65 protein (e.g., the HLA-A ${ }^{\star} 0201$-restricted CMVpp65495-503 peptide) are known to be potent inducers of CTLs (Oelke et al., 2003; Paine et al., 2007). Because the known peptide epitopes are restricted to certain HLA alleles, the use of HLA-restricted peptides cannot exploit the full range of HLA diversity present in the patient. Furthermore, the use of HLA class I immunogenic peptides mainly leads to the generation of CD8 + T cells, resulting in the generation of an immune response restricted to cytotoxic T cells.

\section{ADOPTIVE T-CELL THERAPY FOR EBV INFECTION}

Adoptive T-cell therapy using EBV-CTLs has been successfully employed for prophylaxis and treatment of PTLD in high-risk patients (Haque et al., 2007; Heslop et al., 2010; Shen et al., 2011). EBV-transformed B-lymphoblastoid cell lines (B-LCLs) are established as antigen-presenting cells (APCs) for the generation of EBV-specific T cells. Following this approach, Tanzina Haque and colleagues (University of Edinburgh, UK) established and used a bank of frozen EBV-specific CTLs generated from the peripheral blood of Scottish blood donors to treat patients with progressive PTLD with CTLs selected on the basis of the best HLA-matches between the CTL donor and PTLD patient (Wilkie et al., 2004; Haque et al., 2007). In this multicenter clinical phase II trial, CTLs showed high efficacy varying according to the degree of HLA-match (at least 3/6) and did not induce any GvHD. Haque and colleagues demonstrated that the transfer of partially HLA-matched EBV-CTLs grown from healthy donors by repetitive antigenic stimulation is safe and results in 
tumor regression in about $60 \%$ of PTLD patients unresponsive to at least one prior treatment (Haque et al., 2007, 2010). In a study by Doubrovina et al., 49 HSCT patients with biopsyproven EBV-lymphoproliferative disease (EBV-LPD) were treated with either HLA-compatible DLIs or HLA-compatible or HLAdisparate EBV-specific CTLs (Doubrovina et al., 2012). Acute GvHD was observed in $17 \%$ of all DLI recipients but in no EBVCTL recipients. The data further supports the findings of Haque et al. indicating that EBV-CTLs from healthy, partially HLAmatched third-party donors provide an easily accessible source of effector T cells for the treatment of EBV-associated PTLD (Bollard et al., 2012; Doubrovina et al., 2012).

Nevertheless, the use of EBV-transformed cells as APCs to generate EBV-specific T cells for clinical use has three major limitations: (1) The manufacturing process for the B-LCL-based generation of sufficient numbers of EBV-CTLs for clinical use takes approximately 3 months (half for the generation of B-LCLs and half for T-cell expansion). Consequently, the production of EBVCTLs for the individual patient with PTLD required diligent identification of patients at risk. Furthermore, the process is difficult to standardize and poses a potential biohazard due to the presence of live viruses. (2) So far, EBV-CTLs have mostly been manufactured from autologous peripheral blood mononuclear cells by repetitive in vitro stimulation with EBV antigens presented by APCs. In children, the lack of EBV infection prior to organ transplantation is an additional obstacle to the generation of sufficient numbers of EBV-CTLs. (3) The coverage of latency types is incomplete. Understanding the latency types of EBV is important for the effective design of adoptive T-cell strategies. While EBVtransformed B-LCLs express viral antigens representing latency type III (10 viral proteins), these cells might not be useful for generating specific T cells that effectively target late PTLDs expressing latency type II [only three viral proteins EBV nuclear antigen1 (EBNA-1), late membrane proteins (LMP) LMP1 and LMP2 expressed] or latency type I tumors (e.g., Burkitt's lymphoma) [see review in (Bollard et al., 2012)]. The antigenic specificity of T cells generated by this method is further limited by the set of EBV proteins available in the B-LCLs - they contain mostly proteins from the early replication cycle (e.g., EBNA1-3) and no lytic proteins like BZLF. Unfortunately, EBNA-1, which is expressed in all three latency types, is poorly immunogenic (Thorley-Lawson and Allday, 2008). This was confirmed in studies analyzing the frequency of EBV-specific memory T cells in response to three commercially available peptide pools (EBNA-1, BZLF1, and LMP2A) in 195 healthy EBV-seropositive blood and platelet donors. It has been found that T-cell populations against the BZLF1-derived peptide pool were the most frequent in seropositive donors, as reflected by a high number of responders: 112 (57\%) vs. 90 (49\%) for EBNA-1 and 64 (33\%) for LMP2A (Sukdolak et al., submitted).

\section{ADOPTIVE T-CELL THERAPY FOR ADV INFECTION}

Feuchtinger et al. clearly demonstrated that children with ADVassociated mortality had no ADV-specific T cells, whereas patients who cleared ADV infection had normal frequencies of antiviral T cells (Feuchtinger et al., 2006). Since an increased risk of adenoviral infection in immunocompromised patients has been shown to correlate with low numbers of T cells, efforts have been made over the past years to identify immunogenic ADV-derived epitopes. As of now, the 53 known human serotypes (ADV1 to ADV53) are classified into seven species (A to $G$ ). The most prevalent serotypes in transplant patients are ADV1, 2, 4, 5, 41, and 31 . Hexon, the major capsid protein, serves as the immunodominant target antigen across the different serotypes of ADV. A few hexon-derived $\mathrm{CD}^{+}{ }^{+}$T-cell epitopes for ADV species $\mathrm{C}$ have been identified and, for the most of them their clinical relevance remains unclear. This makes diagnosis and treatment very challenging. These epitopes are highly conserved, suggesting that ADV-specific T cells can cross-react with ADV serotypes and may therefore provide protection against a wide range of ADV strains (Zandvliet et al., 2010). Feuchtinger et al. tested the specific T-cell response to both hexon protein and whole ADV in HSCT donors and found that $10.5 \%$ of donors had a detectable T-cell response to whole ADV but no response to hexon protein, and $17 \%$ of donors had no detectable T-cell response to ADV (Feuchtinger et al., 2008). Zandvliet et al. were able to detect specific $\mathrm{CD} 8^{+} \mathrm{T}$ cells in 6/16 healthy donors after stimulation with 15-mer hexon peptide pool, while stimulation with peptides corresponding to known $\mathrm{CD}^{+}$hexon epitopes induced responses in $3 / 16$ donors (Zandvliet et al., 2010). These studies clearly indicate the need to identify more immunodominant ADV epitopes.

\section{STRATEGIES FOR ISOLATION OF ANTIGEN-SPECIFIC T CELLS FOR ADOPTIVE T-CELL THERAPY}

Direct selection of virus-specific $\mathrm{T}$ cells without long-term ex vivo stimulation and manipulation is an attractive way to generate clinical-grade antiviral $\mathrm{T}$ cells. The two main approaches are separation by the use of cytokine secretion assays [e.g., interferongamma (IFN- $\gamma$ ) secretion assay (Rauser et al., 2004; Feuchtinger et al., 2008, 2010; Mackinnon et al., 2008; Moosmann et al., 2010; Peggs et al., 2011)] and isolation by the use of peptideMHC (pMHC) multimers (Cobbold et al., 2005; Yao et al., 2008; Casalegno-Garduno et al., 2010; Schmitt et al., 2011). Direct isolation of antigen-specific T-cells by stimulation with antigenic peptides, proteins, or peptide-pools followed by cytokine capture and magnetic isolation is a rapid method of producing antiviral T-cells according to GMP guidelines (Rauser et al., 2004). It avoids safety and regulatory issues associated with prolonged T-cell culture and potential viral biohazards. Cytokine secretion assays using recombinant proteins or synthetic peptide pools consisting of overlapping peptides spanning an entire immunodominant protein are not restricted by HLA variations, and they enable the generation of CD4+ and/or CD8+ T-cell responses to multiple epitopes (Rauser et al., 2004). In the case of CMV 2, EBV 3, and ADV 1, GMP-grade peptide pools covering the viral proteins pp65 and IE-1 (CMV); LMP-2A, EBNA-1, and BZLF-1 (EBV); and the hexon (ADV) are now available for the generation of clinical-grade antiviral CD4+ and CD8+ T cells, irrespective of the HLA-type. It is known that specific CD4+ T-cell help is required to elicit and promote an efficient CD8+restricted CTL response to viral antigens. CD4+ T cells secrete various cytokines to regulate and coordinate the function of $\mathrm{T}$ cells and other immune cells. They are also known to be the most effective cell population in clearing infections, such as ADV 
(Feuchtinger et al., 2006). Unfortunately, compared to the isolation of T cells by pMHC multimer technologies the purity is lower and alloreactivity of $\mathrm{T}$ cells might result in undesirable immune responses especially in HLA-mismatched or haploidentical settings. Nevertheless, clinical trials showed no increase in GvHD or graft rejection after adoptive immunotherapy using IFN- $\gamma$ isolated antiviral T cells (Feuchtinger et al., 2006; Peggs et al., 2011; Doubrovina et al., 2012).

The pMHC multimer technology requires knowledge of immunodominant HLA-restricted peptide epitopes and enables the isolation of either antigen-specific CD8 $+\mathrm{T}$ cells ( $\mathrm{pMHC}$ class I multimers) or CD4 $+\mathrm{T}$ cells (pMHC class II multimers) of high purity. It is still difficult to generate the respective multimers needed for CD4+ T-cell isolation. Cobbold and colleagues, the first investigators to use tetramer-purified CMV-specific CD8+ $\mathrm{T}$ cells for adoptive transfer, were able to detect functionally active antiviral $\mathrm{T}$ cells within 10 days (Cobbold et al., 2005). In a study by Uhlin et al., tetramers corresponding to two EBV antigens were used to treat a patient suffering from PTLD after cord blood (CB) transplantation (Uhlin et al., 2010). Reversible pMHC multimers (streptamers, histamers), the latest generation of pMHC multimer technologies, were developed in order to isolate antigen-specific $\mathrm{T}$ cells without altering their functional status (Knabel et al., 2002; Tischer et al., 2012) and are already used clinical applications (Schmitt et al., 2011). Although the results are promising, this technology is limited to those donors who express an HLA allele with known viral epitopes and have sufficient numbers of memory $\mathrm{T}$ cells present in the peripheral blood.

$\mathrm{T}$ cells for adoptive immunotherapy could potentially be isolated from a $\mathrm{T}$ lymphocyte pool phenotypically identified as CD45RA + CD62L + naïve $(\mathrm{N}), \mathrm{CD} 45 \mathrm{RO}+\mathrm{CD} 62 \mathrm{~L}+$ central memory (TCM), and CD62L- effector memory (TEM) T-cells subsets. These cells differ in phenotype, function, and homing (Sallusto et al., 2004). Recently it was shown, that although TEM have proliferative potential in vitro, these cells fail to survive in primates in vivo (Berger et al., 2008). These results most likely have implications for the types of $\mathrm{T}$ cells that should be selected for adoptive transfer.

\section{DO WE NEED THIRD-PARTY T-CELL DONORS?}

The first clinical trials showed that $\mathrm{T}$ cells generated by the above-described procedures can be successfully used to treat viral infection, reactivation, or virus-induced malignancies after stem cell and SOT. It was also shown that adoptive immunotherapy with donor-derived virus-specific CTLs generated in vitro can effectively prevent the clinical manifestation of these viruses with no acute toxicity or increased risk of GvHD. In allogeneic stem cell transplantation, seropositive stem cell donors can usually serve as $\mathrm{T}$ cell donors and are available for T-cell donation. However, some seropositive donors may not consent, may be unavailable to provide $\mathrm{T}$ cells, or may not have enough antiviral memory $\mathrm{T}$ cells in their blood despite seropositivity. Recent studies have also shown that granulocyte colony-stimulating factor (G-CSF) mobilization has a long-term negative effect on the functional activity of T cells (Franzke et al., 2003; Toh et al., 2009). Bunse et al. (in preparation), suggesting that antiviral memory $\mathrm{T}$ cells from stem cell donors might not be the best source. Furthermore, delayed hematologic engraftment and immune reconstitution are a major problem in patients receiving $\mathrm{CB}$ transplants. These problems may be attributable to a low stem cell dose, small numbers of transferred $\mathrm{T}$ cells, the absence of memory $\mathrm{T}$ cells within the $\mathrm{CB}$ grafts, or the hyporesponsiveness of CB APCs. Therefore, these patients are at high risk of developing viral complications as are patients receiving transplants from seronegative donors or SOT patients receiving organ grafts from deceased donors. CMV-seropositive immunocompromised patients $(\mathrm{R}+)$ with transplants from seronegative donors $(\mathrm{D}-)$ ) were shown to have a high risk of CMV disease (Zhou et al., 2009; Ugarte-Torres et al., 2011). It was reported that CMV reactivation occurs in $96 \%$ of $\mathrm{D}+\mathrm{R}+$ patients but in less than $50 \%$ of $\mathrm{D}+\mathrm{R}$ - patients (Lilleri et al., 2008; Borchers et al., 2011). Therefore, adoptive transfer of virus-specific CTL is not a viable option for high-risk patients $(\mathrm{R}+)$ with seronegative donors $(\mathrm{D}-)$.

Under these conditions, partially HLA-matched virus-specific $\mathrm{T}$ cells from healthy seropositive individuals could be a successful alternative and could play a significant role in the prevention and treatment of viral infections in transplant recipients. Studies on the use of HLA-matched T-cells from third-party donors for the treatment of stem cell and organ recipients are currently in progress.

The third-party approach was first successfully tested in SOT and HSCT patients with EBV-associated PTLD at the University of Edinburgh (Haque et al., 2002, 2007; Wilkie et al., 2004). As mentioned in chapter 4.2 Haque and colleagues showed that partially HLA-matched EBV-specific T cells (at least 3/6) produce a $65 \%$ response rate and a $42 \%$ complete response rate in PTLD patients after SOT, indicating that the transferred EBV-specific T cells were highly effective and did not induce any GvHD (Haque et al., 2007, 2010). Later studies (Barker et al., 2010; Uhlin et al., 2010; Doubrovina et al., 2012) including CB transplant patients confirmed these results. O'Reilly and colleagues used partially HLA-matched EBV-specific T cells to treat EBV lymphoproliferative disease in allogeneic HSCT recipients and achieved complete or partial remission in 68\% (Barker et al., 2010; Doubrovina et al., 2012).

The effectiveness of third-party donor-derived T cells in treating $\mathrm{CMV}$ and $\mathrm{ADV}$ is now being investigated in various clinical trials (e.g., in Memorial Sloan-Kettering Cancer Center's phase II trial on the treatment of CMV). Feuchtinger et al. reported their results obtained with $\mathrm{T}$ cells from two third-party, partially HLAmatched, unrelated CMV-specific T-cell donors to treat CB transplanted patients (Feuchtinger et al., 2010). The cells were rapidly isolated from the donors using an IFN $-\gamma$ cytokine secretion assay after brief stimulation of peripheral blood mononuclear cells with CMV pp65. In vivo expansion of CMV-specific T cells and clearance of CMV infection was observed in one patient (Schottker et al., 2008; Feuchtinger et al., 2010). Third-party virus-specific $\mathrm{T}$ cells directed against ADV were also shown to be effective for the eradication of ADV (Qasim et al., 2011). Rooney and Leen recently investigated the use of banks of third-party $\mathrm{T}$ cells specific for CMV, EBV, and ADV in HSCT patients and observed a high $(>70 \%)$ response rate to all three viruses, even in case of only one HLA allele match between the CTL line and the recipient (Gerdemann et al., 2012). 


\section{THE ALLOGENEIC T-CELL DONOR REGISTRY}

First results using $\mathrm{T}$ cells from partially HLA-matched thirdparty donors are promising. The data indicate that allogeneic T-cell therapy is an attractive option for patients suffering from viral infections after allogeneic HSCT or organ transplantation. Therefore, we hypothesize that a registry of HLA-typed allogeneic T-cell donors typed for virus-specific $\mathrm{T}$ cells would enable rapid availability of $\mathrm{T}$ cells for adoptive immunotherapy of virusassociated diseases in transplant recipients without an adequate T-cell donor. This registry might provide a stand-alone off-theshelf product.

To gain more insight into virus-specific memory T-cell pools in healthy donors and to identify the most efficient antigens for adoptive immunotherapy, we determined the frequencies of virus-specific memory $\mathrm{T}$ cells in healthy donors. To date, T-cell frequencies have been determined in more than 300 HLA high-resolution typed donors at Hannover Medical School's Institute for Transfusion Medicine by INF- $\gamma$ enzymelinked immunospot (ELISpot) assay and flow cytometry using pMHC multimers (Sukdolak et al., submitted). Using these wellestablished methods of T-cell monitoring (Cox et al., 2006; Hadrup and Schumacher, 2010), we assessed the frequencies of $\mathrm{T}$ cells against GMP-quality peptides and peptide pools derived from viral proteins known to be immunodominant or subdominant. For example, phosphoprotein 65 (pp65) and immediate early (IE)-1 were used for CMV (Wills et al., 1996), BZLF1, nuclear antigen (EBNA) -1 and latent membrane protein $2 \mathrm{~A}$ (LMP2A) for EBV (Houssaint et al., 2001), and hexon, the major capsid protein of ADV, for ADV (Leen et al., 2008). For optimal T-cell help and cytotoxic response, the T-cell population should consist of CD4+ and CD8+ virus-specific T cells. For high efficiency, these cells should also target various viral epitopes. For each virus studied, we identified at least $61 \%$ potential CTL donors with highly significant differences in frequencies of $\mathrm{T}$ cells against each of the six viral antigens tested: pp65 and IE-1 (CMV), BZLF1, LMP2A, and EBNA1 (EBV), and hexon (ADV).

All CMV-seropositive donors were reactive to the CMV pp65 peptide pool, whereas only $79 \%$ reacted with IE-1. One hundred and seventy three of the EBV-seropositive donors had antigenspecific T cells that reacted with at least one of three EBV peptide pools, showing highest frequencies for BZLF1, and $73 \%$ of the ADV-seropositive donors reacted with the hexon peptide pool. Interestingly we found that in short-term in vitro peptide stimulation assays for ADV and EBV a donor response to a certain peptide may not be determined on day 0 . Peptide-specific $T$ cells were detected by multimer staining, but overall frequencies were lower than those obtained for the corresponding peptide pools. The results of our study demonstrate that, depending on the antigen used, no antiviral $\mathrm{T}$ cells can be detected in approximately one-third of donors despite seropositivity, and that serological testing for CMV by the standard ELISA technique gives false-positive results in approximately $10 \%$ of donors. It is important to remember that GvHD remains a dreaded side effect and there is a particularly risk of alloreactivity, especially in partially-HLA-matched settings (Amir et al., 2010; D'Orsogna et al., 2010; Qasim et al., 2011). Therefore, we developed a modified granzyme B ELISpot assay to detect T-cell specificity and alloreactivity against patient cells and used it to test T-cell effector function against unloaded PBMCs, (HLA class I-negative) K562 cells and "patient unloaded and antigen-loaded PBMCs." This method can also be used to identify the best HLA-matched allogeneic antiviral CTL donor. The HLA-types of CTLs with the highest specific killing of "patient antigen-loaded PBMCs" were identified and considered in partially HLA-matched allogeneic T-cell therapy.

The results were used to establish a registry of potential T-cell donors (allogeneic T-cell donor registry, alloTCDR) with highly virus-specific T-cell precursors. The alloTCDR database will document the donors' HLA-type (class I and II high resolution), virus serology (ADV, CMV, and EBV), virus-specific T-cell frequencies, best T-cell detection method, and results of functional and alloreactivity assays. This registry of HLA-typed allogeneic T-cell donors profiled for virus-specific $\mathrm{T}$ cells will ensure the rapid availability of $\mathrm{T}$ cells for adoptive immunotherapy of virusassociated diseases in transplant recipients without an adequate T-cell donor.

\section{SUMMARY}

Antigen-specific $\mathrm{T}$ cells can be effectively used in the treatment of viral infection or reactivation after stem cell and SOT. So far most studies did not show significant increase in the development of acute toxicity or increased risk of GvHD following T-cell transfer. Unfortunately, for patients receiving an allogeneic CB transplant, a transplant from a virus-naïve donor or a transplant from a cadaveric donor no T-cell donor will be available. Furthermore, it was shown that in some cases no antiviral memory $\mathrm{T}$ cells are present in the donor despite seropositivity, and that G-CSF treatment has a negative effect on antiviral cell function. Third-party partially HLA-matched virus-specific $\mathrm{T}$ cells from healthy seropositive individuals may be an option, which can be successfully employed under these circumstances. In future, we will extend the typing and profiling of potential thirdparty donors to include the T-cell frequencies of other viruses, such as polyoma virus $\mathrm{BK}$, human herpesvirus 6 , and invasive fungal pathogens such as Aspergillus. The registry of unrelated HLA-typed allogeneic T-cell donors profiled for virus-specific $\mathrm{T}$ cells will ensure the rapid availability of $\mathrm{T}$ cells for adoptive immunotherapy of pathogen-associated diseases in transplant recipients.

\section{ACKNOWLEDGMENTS}

The authors would like to thank Cinja Sukdolak, Carola Bunse, Sylvia Borchers, Sabine Tischer, Stephan Immenschuh, Murielle Verboom, Lilia Goudeva and Hans-Gert Heuft for their assistance and for helpful discussions. This work is supported in part by funding from the German Research Foundation (Deutsche Forschungsgemeinschaft, DFG) for the REBIRTH (From Regenerative Biology to Reconstructive Therapy) Cluster of Excellence, the Integrated Research and Treatment Center Transplantation (IFB-Tx) funded by the German Federal Ministry of Education and Research (reference number: 01EO0802), the German Children's Cancer Research Fund (Deutsche Kinderkrebshilfe), and the Immunotherapy Foundation (Stiftung Immuntherapie). 


\section{REFERENCES}

Amir, A., Shapiro, R., Shulman, L. M., Mor, E., Steinberg, R., Fleishhacker, H., et al. (2011). BK virus infection and its effect on renal function in pediatric liver-transplant recipients: a cross-sectional, longitudinal, prospective study. Transplantation 92, 943-946.

Amir, A. L., D’Orsogna, L. J., Roelen, D. L., van Loenen, M. M., Hagedoorn, R. S., de Boer, R., et al. (2010). Allo-HLA reactivity of virus-specific memory T cells is common. Blood 115, 3146-3157.

Barker, J. N., Doubrovina, E., Sauter, C., Jaroscak, J. J., Perales, M. A., Doubrovin, M., et al. (2010). Successful treatment of EBVassociated posttransplantation lymphoma after cord blood transplantation using thirdparty EBV-specific cytotoxic T lymphocytes. Blood 116, 5045-5049.

Battiwalla, M., Paplham, P., Almyroudis, N. G., McCarthy, A., Abdelhalim, A., Elefante, A., et al. (2007). Leflunomide failure to control recurrent cytomegalovirus infection in the setting of renal failure after allogeneic stem cell transplantation. Transpl. Infect. Dis. 9, 28-32.

Berger, C., Jensen, M. C., Lansdorp, P. M., Gough, M., Elliott, C., and Riddell, S. R. (2008). Adoptive transfer of effector CD8+ T cells derived from central memory cells establishes persistent $\mathrm{T}$ cell memory in primates. J. Clin. Invest. 118, 294-305.

Berger, C., Turtle, C. J., Jensen, M. C., and Riddell, S. R. (2009). Adoptive transfer of virus-specific and tumorspecific T cell immunity. Curr. Opin. Immunol. 21, 224-232.

Boeckh, M., and Ljungman, P. (2009). How we treat cytomegalovirus in hematopoietic cell transplant recipients. Blood 113, 5711-5719.

Bollard, C. M., Rooney, C. M., and Heslop, H. E. (2012). T-cell therapy in the treatment of post-transplant lymphoproliferative disease. Nat. Rev. Clin. Oncol. 9, 510-519.

Borchers, S., Luther, S., Lips, U., Hahn, N., Kontsendorn, J., Stadler, M., et al. (2011). Tetramer monitoring to assess risk factors for recurrent cytomegalovirus reactivation and reconstitution of antiviral immunity post allogeneic hematopoietic stem cell transplantation. Transpl. Infect. Dis. 13, 222-236.

Brestrich, G., Zwinger, S., Fischer, A., Schmuck, M., Rohmhild, A., Hammer, M. H., et al. (2009). Adoptive T-cell therapy of a lung transplanted patient with severe
CMV disease and resistance to antiviral therapy. Am. J. Transplant. 9, 1679-1684.

Breuer, S., Rauch, M., Matthes-Martin, S., and Lion, T. (2012). Molecular diagnosis and management of viral infections in hematopoietic stem cell transplant recipients. Mol. Diagn. Ther. 16, 63-77.

Broers, A. E., van Der Holt, R., van Esser, J. W., Gratama, J. W., Henzen-Logmans, S., KuenenBoumeester, V., et al. (2000). Increased transplant-related morbidity and mortality in CMVseropositive patients despite highly effective prevention of CMV disease after allogeneic T-cell-depleted stem cell transplantation. Blood 95, 2240-2245.

Bruno, B., Gooley, T., Hackman, R. C., Davis, C., Corey, L., and Boeckh, M. (2003). Adenovirus infection in hematopoietic stem cell transplantation: effect of ganciclovir and impact on survival. Biol. Blood Marrow Transplant. 9, 341-352.

Carlsson, B., Cheng, W. S., Totterman, T. H., and Essand, M. (2003). Ex vivo stimulation of cytomegalovirus (CMV)-specific T cells using CMV pp65-modified dendritic cells as stimulators. Br. J. Haematol. 121, 428-438.

Casalegno-Garduno, R., Schmitt, A., Yao, J., Wang, X., Xu, X., Freund, M. et al. (2010). Multimer technologies for detection and adoptive transfer of antigen-specific T cells. Cancer Immunol. Immunother. 59, 195-202.

Chakrabarti, S., Mautner, V., Osman, H., Collingham, K. E., Fegan, C. D., Klapper, P. E., et al. (2002). Adenovirus infections following allogeneic stem cell transplantation: incidence and outcome in relation to graft manipulation, immunosuppression, and immune recovery. Blood 100, 1619-1627.

Choi, S. J., Lee, J. H., Lee, J. H., Kim, S., Lee, Y. S., Seol, M., et al. (2005). Treatment of relapsed acute lymphoblastic leukemia after allogeneic bone marrow transplantation with chemotherapy followed by G-CSFprimed donor leukocyte infusion: a prospective study. Bone Marrow Transplant. 36, 163-169.

Cobbold, M., Khan, N., Pourgheysari, B., Tauro, S., McDonald, D., Osman, H., et al. (2005). Adoptive transfer of cytomegalovirus-specific CTL to stem cell transplant patients after selection by HLA-peptide tetramers. J. Exp. Med. 202, 379-386.

Cohen, J. I. (2000). Epstein-Barr virus infection. N. Engl. J. Med. 343, 481-492.
Collins, R. H. Jr., Goldstein, S., Giralt, S., Levine, J., Porter, D., Drobyski, W., et al. (2000). Donor leukocyte infusions in acute lymphocytic leukemia. Bone Marrow Transplant. 26, 511-516.

Cox, J. H., Ferrari, G., and Janetzki, S. (2006). Measurement of cytokine release at the single cell level using the ELISPOT assay. Methods 38, 274-282.

Cwynarski, K., Ainsworth, J., Cobbold, M., Wagner, S., Mahendra, P. Apperley, J., et al. (2001). Direct visualization of cytomegalovirusspecific T-cell reconstitution after allogeneic stem cell transplantation. Blood 97, 1232-1240.

D’Orsogna, L. J., Roelen, D. L. Doxiadis, I. I., and Claas, F. H. (2010). Alloreactivity from human viral specific memory T-cells. Transpl. Immunol. 23, 149-155.

Doubrovina, E., Oflaz-Sozmen, B. Prockop, S. E., Kernan, N. A., Abramson, S., Teruya-Feldstein, J., et al. (2012). Adoptive immunotherapy with unselected or EBV-specific $\mathrm{T}$ cells for biopsy-proven EBV+ lymphomas after allogeneic hematopoietic cell transplantation. Blood 119, 2644-2656.

Ebner, K., Suda, M., Watzinger, F., and Lion, T. (2005). Molecular detection and quantitative analysis of the entire spectrum of human adenoviruses by a two-reaction real-time PCR assay. J. Clin. Microbiol. 43, 3049-3053.

Einsele, H., Hebart, H., KauffmannSchneider, C., Sinzger, C., Jahn, G., Bader, P., et al. (2000). Risk factors for treatment failures in patients receiving PCR-based preemptive therapy for CMV infection. Bone Marrow Transplant. 25, 757-763.

Einsele, H., Kapp, M., and Grigoleit, G. U. (2008). CMV-specific T cell therapy. Blood Cells Mol. Dis. 40, 71-75.

Elkington, R., Walker, S., Crough, T. Menzies, M., Tellam, J., Bharadwaj, M., et al. (2003). Ex vivo profiling of CD8+-T-cell responses to human cytomegalovirus reveals broad and multispecific reactivities in healthy virus carriers. J. Virol. 77, 5226-5240.

Feuchtinger, T., Lucke, J., Hamprecht, K., Richard, C., Handgretinger, R., Schumm, M., et al. (2005) Detection of adenovirus-specific $T$ cells in children with adenovirus infection after allogeneic stem cell transplantation. Br. J. Haematol. 128, 503-509.

Feuchtinger, T., Matthes-Martin, S., Richard, C., Lion, T., Fuhrer, M., Hamprecht, K., et al. (2006). Safe adoptive transfer of virus-specific T-cell immunity for the treatment of systemic adenovirus infection after allogeneic stem cell transplantation. Br. J. Haematol. 134, 64-76.

Feuchtinger, T., Opherk, K., Bethge, W. A., Topp, M. S., Schuster, F. R. Weissinger, E. M., et al. (2010). Adoptive transfer of pp65-specific T cells for the treatment of chemorefractory cytomegalovirus disease or reactivation after haploidentical and matched unrelated stem cell transplantation. Blood 116, 4360-4367.

Feuchtinger, T., Richard, C., Joachim, S., Scheible, M. H., Schumm, M., Hamprecht, K., et al. (2008). Clinical grade generation of hexon-specific $\mathrm{T}$ cells for adoptive T-cell transfer as a treatment of adenovirus infection after allogeneic stem cell transplantation. J. Immunother. 31, 199-206.

Fowler, C. J., Dunlap, J., Troyer, D., Stenzel, P., Epner, E., and Maziarz, R. T. (2010). Life-threatening adenovirus infections in the setting of the immunocompromised allogeneic stem cell transplant patients. Adv. Hematol. 2010:601548. doi: $10.1155 / 2010 / 601548$

Franzke, A., Piao, W., Lauber, J., Gatzlaff, P., Konecke, C., Hansen, W., et al. (2003). G-CSF as immune regulator in $\mathrm{T}$ cells expressing the G-CSF receptor: implications for transplantation and autoimmune diseases. Blood 102, 734-739.

Fuji, S., Kapp, M., Grigoleit, G. U., and Einsele, H. (2011). Adoptive immunotherapy with virus-specific T cells. Best Pract. Res. Clin. Haematol. 24, 413-419.

Fujita, Y., Leen, A. M., Sun, J., Nakazawa, Y., Yvon, E., Heslop, H. E., et al. (2008a). Exploiting cytokine secretion to rapidly produce multivirus-specific $\mathrm{T}$ cells for adoptive immunotherapy. J. Immunother. 31, 665-674.

Fujita, Y., Rooney, C. M., and Heslop, H. E. (2008b). Adoptive cellular immunotherapy for viral diseases. Bone Marrow Transplant. 41, 193-198.

Garcia-Vidal, C., Upton, A., Kirby, K. A., and Marr, K. A. (2008) Epidemiology of invasive mold infections in allogeneic stem cell transplant recipients: biological risk factors for infection according to time after transplantation. Clin. Infect. Dis. 47, 1041-1050.

Gerdemann, U., Katari, U., Christin, A. S., Cruz, C. R., Tripic, T., Rousseau, A., et al. (2012). Cytotoxic T lymphocytes simultaneously targeting multiple tumor-associated antigens 
to treat EBV negative lymphoma. Mol. Ther. 19, 2258-2268.

Gooley, T. A., Chien, J. W., Pergam, S. A., Hingorani, S., Sorror, M. L., Boeckh, M., et al. (2010). Reduced mortality after allogeneic hematopoietic-cell transplantation. N. Engl. J. Med. 363, 2091-2101.

Gottschalk, S., Rooney, C. M., and Heslop, H. E. (2005). Posttransplant lymphoproliferative disorders. Аnnu. Rev. Med. 56, 29-44.

Greenberg, P. D., Reusser, P., Goodrich, J. M., and Riddell, S. R. (1991). Development of a treatment regimen for human cytomegalovirus (CMV) infection in bone marrow transplantation recipients by adoptive transfer of donor-derived CMVspecific $\mathrm{T}$ cell clones expanded in vitro. Ann. N.Y. Acad. Sci. 636, 184-195.

Guppy, A. E., Rawlings, E., Madrigal, J. A., Amlot, P. L., and Barber, L. D. (2007). A quantitative assay for Epstein-Barr Virus-specific immunity shows interferon-gamma producing CD8+ T cells increase during immunosuppression reduction to treat posttransplant lymphoproliferative disease. Transplantation 84, 1534-1539.

Hadrup, S. R., and Schumacher, T. N. (2010). MHC-based detection of antigen-specific CD8+ T cell responses. Cancer Immunol. Immunother. 59, 1425-1433.

Haque, T., McAulay, K. A., Kelly, D., and Crawford, D. H. (2010). Allogeneic T-cell therapy for Epstein-Barr virus-positive posttransplant lymphoproliferative disease: long-term follow-up. Transplantation 90, 93-94.

Haque, T., Wilkie, G. M., Jones, M. M., Higgins, C. D., Urquhart, G., Wingate, P., et al. (2007). Allogeneic cytotoxic T-cell therapy for EBVpositive posttransplantation lymphoproliferative disease: results of a phase 2 multicenter clinical trial. Blood 110, 1123-1131.

Haque, T., Wilkie, G. M., Taylor, C., Amlot, P. L., Murad, P., Iley, A., et al. (2002). Treatment of Epstein-Barrvirus-positive post-transplantation lymphoproliferative disease with partly HLA-matched allogeneic cytotoxic $\mathrm{T}$ cells. Lancet 360, 436-442.

Heslop, H. E., Slobod, K. S., Pule, M. A., Hale, G. A., Rousseau, A., Smith, C. A., et al. (2010). Longterm outcome of EBV-specific T-cell infusions to prevent or treat EBVrelated lymphoproliferative disease in transplant recipients. Blood 115, 925-935.
Hoffman, J. A. (2009). Adenovirus infections in solid organ transplant recipients. Curr. Opin. Organ Transplant. 14, 625-633.

Houssaint, E., Saulquin, X., Scotet, E., and Bonneville, M. (2001). Immunodominant CD8 T cell response to Epstein-Barr virus. Biomed. Pharmacother. 55, 373-380.

Khan, N. (2007). The immunological burden of human cytomegalovirus infection. Arch. Immunol. Ther. Exp. (Warsz) 55, 299-308.

Khanna, N., Stuehler, C., Conrad, B., Lurati, S., Krappmann, S., Einsele, H., et al. (2011). Generation of a multipathogen-specific T-cell product for adoptive immunotherapy based on activation-dependent expression of CD154. Blood 118, 1121-1131.

Knabel, M., Franz, T. J., Schiemann, M., Wulf, A., Villmow, B., Schmidt, B. et al. (2002). Reversible MHC multimer staining for functional isolation of T-cell populations and effective adoptive transfer. Nat. Med. 8 , 631-637.

Kuehnle, I., Huls, M. H., Liu, Z., Semmelmann, M., Krance, R. A., Brenner, M. K., et al. (2000). CD20 monoclonal antibody (rituximab) for therapy of Epstein-Barr virus lymphoma after hemopoietic stem-cell transplantation. Blood 95, 1502-1505.

Landgren, O., Gilbert, E. S., Rizzo, J. D., Socie, G., Banks, P. M., Sobocinski, K. A., et al. (2009). Risk factors for lymphoproliferative disorders after allogeneic hematopoietic cell transplantation. Blood 113, 4992-5001.

Lankester, A. C., Heemskerk, B., Claas, E. C., Schilham, M. W., Beersma, M. F., Bredius, R. G., et al. (2004). Effect of ribavirin on the plasma viral DNA load in patients with disseminating adenovirus infection. Clin. Infect. Dis. 38, 1521-1525.

Leen, A. M., Christin, A., Khalil, M., Weiss, H., Gee, A. P., Brenner, M. K., et al. (2008). Identification of hexon-specific CD4 and CD8 T-cell epitopes for vaccine and immunotherapy. J. Virol. 82, 546-554.

Leen, A. M., Myers, G. D., Sili, U., Huls, M. H., Weiss, H., Leung, K. S., et al. (2006). Monoculturederived $\mathrm{T}$ lymphocytes specific for multiple viruses expand and produce clinically relevant effects in immunocompromised individuals. Nat. Med. 12, 1160-1166.

Lilleri, D., Fornara, C., Chiesa, A., Caldera, D., Alessandrino, E. P., and Gerna, G. (2008). Human cytomegalovirus-specific $\mathrm{CD} 4+$ and CD8+ T-cell reconstitution in adult allogeneic hematopoietic stem cell transplant recipients and immune control of viral infection. Haematologica 93, 248-256.

Lilleri, D., Gerna, G., Zelini, P., Chiesa, A., Rognoni, V., Mastronuzzi, A., et al. (2012). Monitoring of human cytomegalovirus and virus-specific $\mathrm{T}$-cell response in young patients receiving allogeneic hematopoietic stem cell transplantation. PLoS ONE 7:e41648. doi 10.1371/journal.pone.0041648

Lindemans, C. A., Leen, A. M., and Boelens, J. J. (2010). How I treat adenovirus in hematopoietic stem cell transplant recipients. Blood 116, 5476-5485.

Lion, T., Baumgartinger, R., Watzinger, F., Matthes-Martin, S., Suda, M. Preuner, S., et al. (2003). Molecular monitoring of adenovirus in peripheral blood after allogeneic bone marrow transplantation permits early diagnosis of disseminated disease. Blood 102, 1114-1120.

Ljungman, P., Bregni, M., Brune, M., Cornelissen, J., de Witte, T., Dini, G., et al. (2010). Allogeneic and autologous transplantation for haematological diseases, solid tumours and immune disorders: current practice in Europe 2009. Bone Marrow Transplant. 45, 219-234.

Lozza, L., Lilleri, D., Percivalle, E., Fornara, C., Comolli, G., Revello, M. G., et al. (2005). Simultaneous quantification of human cytomegalovirus (HCMV)specific $\mathrm{CD} 4+$ and $\mathrm{CD} 8+\mathrm{T}$ cells by a novel method using monocytederived HCMV-infected immature dendritic cells. Eur. J. Immunol. 35, 1795-1804.

Mackinnon, S., Thomson, K., Verfuerth, S., Peggs, K., and Lowdell, M. (2008). Adoptive cellular therapy for cytomegalovirus infection following allogeneic stem cell transplantation using virusspecific T cells. Blood Cells Mol. Dis. 40, 63-67.

Marr, K. A., Carter, R. A., Crippa, F., Wald, A., and Corey, L. (2002). Epidemiology and outcome of mould infections in hematopoietic stem cell transplant recipients. Clin. Infect. Dis. 34, 909-917.

Meij, P., van Esser, J. W., Niesters, H. G., van Baarle, D., Miedema, F., Blake, N., et al. (2003). Impaired recovery of Epstein-Barr virus (EBV)-specific CD8+ $\mathrm{T}$ lymphocytes after partially $\mathrm{T}$-depleted allogeneic stem cell transplantation may identify patients at very high risk for progressive EBV reactivation and lymphoproliferative disease. Blood 101, 4290-4297.

Moosmann, A., Bigalke, I., Tischer, J., Schirrmann, L., Kasten, J., Tippmer, S., et al. (2010). Effective and longterm control of EBV PTLD after transfer of peptide-selected $\mathrm{T}$ cells. Blood 115, 2960-2970.

Mori, T., Okamoto, S., Matsuoka, S., Yajima, T., Wakui, M., Watanabe, R., et al. (2000). Riskadapted pre-emptive therapy for cytomegalovirus disease in patients undergoing allogeneic bone marrow transplantation. Bone Marrow Transplant. 25, 765-769.

Oelke, M., Maus, M. V., Didiano, D., June, C. H., Mackensen, A., and Schneck, J. P. (2003). Ex vivo induction and expansion of antigenspecific cytotoxic $\mathrm{T}$ cells by HLA-Igcoated artificial antigen-presenting cells. Nat. Med. 9, 619-624.

Olagne, J., Caillard, S., Gaub, M. P., Chenard, M. P., and Moulin, B. (2011). Post-transplant lymphoproliferative disorders: determination of donor/recipient origin in a large cohort of kidney recipients. Am. J. Transplant. 11, 1260-1269.

Paine, A., Oelke, M., Blasczyk, R., and Eiz-Vesper, B. (2007). Expansion of human cytomegalovirus-specific $\mathrm{T}$ lymphocytes from unfractionated peripheral blood mononuclear cells with artificial antigenpresenting cells. Transfusion 47, 2143-2152.

Paine, A., Oelke, M., Tischer, S., Heuft, H. G., Blasczyk, R., and Eiz-Vesper, B. (2010). Soluble recombinant CMVpp65 spanning multiple HLA alleles for reconstitution of antiviral CD4+ and CD8+ T-cell responses after allogeneic stem cell transplantation. J. Immunother. 33, 60-72.

Pappas, P. G., Alexander, B. D., Andes, D. R., Hadley, S., Kauffman, C. A., Freifeld, A., et al. (2010). Invasive fungal infections among organ transplant recipients: results of the Transplant-Associated Infection Surveillance Network (TRANSNET). Clin. Infect. Dis. 50, 1101-1111.

Peggs, K. S., Thomson, K., Samuel, E., Dyer, G., Armoogum, J., Chakraverty, R., et al. (2011). Directly selected cytomegalovirusreactive donor $\mathrm{T}$ cells confer rapid and safe systemic reconstitution of virus-specific immunity following stem cell transplantation. Clin. Infect. Dis. 52, 49-57.

Peggs, K., Verfuerth, S., and Mackinnon, S. (2001). Induction of cytomegalovirus (CMV)-specific T-cell responses using dendritic 
cells pulsed with CMV antigen: a novel culture system free of live CMV virions. Blood 97, 994-1000.

Pidala, J., Tomblyn, M., Nishihori, T., Ayala, E., Field, T., Fernandez, H., et al. (2011). ATG prevents severe acute graft-versus-host disease in mismatched unrelated donor hematopoietic cell transplantation. Biol. Blood Marrow Transplant. 17, 1237-1244.

Qasim, W., Derniame, S., Gilmour, K., Chiesa, R., Weber, M., Adams, S., et al. (2011). Third-party virusspecific $\mathrm{T}$ cells eradicate adenoviraemia but trigger bystander graftversus-host disease. Br. J. Haematol. 154, 150-153.

Rauser, G., Einsele, H., Sinzger, C., Wernet, D., Kuntz, G., Assenmacher, M., et al. (2004). Rapid generation of combined CMV-specific CD4+ and $\mathrm{CD} 8+\mathrm{T}$-cell lines for adoptive transfer into recipients of allogeneic stem cell transplants. Blood 103, 3565-3572.

Rentenaar, R. J., Gamadia, L. E., van DerHoek, N., van Diepen, F. N., Boom, R., Weel, J. F., et al. (2000). Development of virus-specific $\mathrm{CD} 4(+) \mathrm{T}$ cells during primary cytomegalovirus infection. J. Clin. Invest. 105, 541-548.

Riddell, S. R., Reusser, P., and Greenberg, P. D. (1991). Cytotoxic $T$ cells specific for cytomegalovirus: a potential therapy for immunocompromised patients. Rev. Infect. Dis. 13(Suppl. 11), S966-S973.

Runde, V., Ross, S., Trenschel, R., Lagemann, E., Basu, O., RenzingKohler, K., et al. (2001). Adenoviral infection after allogeneic stem cell transplantation (SCT): report on 130 patients from a single SCT unit involved in a prospective multi center surveillance study. Bone Marrow Transplant. 28, 51-57.

Sallusto, F., Geginat, J., and Lanzavecchia, A. (2004). Central memory and effector memory $\mathrm{T}$ cell subsets: function, generation, and maintenance. Annu. Rev. Immunol. $22,745-763$.

Schmitt, A., Tonn, T., Busch, D. H., Grigoleit, G. U., Einsele, H., Odendahl, M., et al. (2011). Adoptive transfer and selective reconstitution of streptamerselected cytomegalovirus-specific CD8+ T cells leads to virus clearance in patients after allogeneic peripheral blood stem cell transplantation. Transfusion 51, 591-599. Schottker, B., Feuchtinger, T., Schumm, M., Klinker, E., Handgretinger, R., Einsele, H., et al. (2008). Five donors-one recipient: modeling a mosaic of granulocytes, natural killer and $\mathrm{T}$ cells from cord-blood and third-party donors. Nat. Clin. Pract. Oncol. 5, 291-295.

Shen, Q., Feng, W., Long, M. S., Duan, X., Jaijakul, S., Arias, C. A., et al. (2011). Multicentric hepatic EBVassociated smooth muscle tumors in an AIDS patient: a case report, investigation of mTOR activation and review of the literature. Int. J. Clin. Exp. Pathol. 4, 421-429.

Solache, A., Morgan, C. L., Dodi, A. I., Morte, C., Scott, I., Baboonian, C., et al. (1999). Identification of three HLA-A ${ }^{*} 0201$-restricted cytotoxic $\mathrm{T}$ cell epitopes in the cytomegalovirus protein pp65 that are conserved between eight strains of the virus. J. Immunol. 163, 5512-5518.

Sun, Q., Pollok, K. E., Burton, R. L., Dai, L. J., Britt, W., Emanuel, D. J., et al. (1999). Simultaneous ex vivo expansion of cytomegalovirus and Epstein-Barr virus-specific cytotoxic $\mathrm{T}$ lymphocytes using Blymphoblastoid cell lines expressing cytomegalovirus pp65. Blood 94, 3242-3250.

Sylwester, A. W., Mitchell, B. L., Edgar, J. B., Taormina, C., Pelte, C., Ruchti, F., et al. (2005). Broadly targeted human cytomegalovirus-specific CD4+ and CD8+ T cells dominate the memory compartments of exposed subjects. J. Exp. Med. 202, 673-685.

Thorley-Lawson, D. A., and Allday, M. J. (2008). The curious case of the tumour virus: 50 years of Burkitt's lymphoma. Nat. Rev. Microbiol. 6, 913-924.

Tischer, S., Kaireit, T., Figueiredo, C., Hiller, O., Maecker-Kolhoff, B., Geyeregger, R., et al. (2012). Establishment of the reversible peptide-major histocompatibility complex (pMHC) class I Histamer technology: tool for visualization and selection of functionally active antigen-specific CD8+ $\mathrm{T}$ lymphocytes. Int. Immunol. 24, 561-572.

Toh, H. C., Sun, L., Soe, Y., Wu, Y., Phoon, Y. P., Chia, W. K., et al. (2009). G-CSF induces a potentially tolerant gene and immunophenotype profile in T cells in vivo. Clin. Immunol. 132, 83-92.

Trappe, R., Oertel, S., Leblond, V., Mollee, P., Sender, M., Reinke, P., et al. (2012). Sequential treatment with rituximab followed by $\mathrm{CHOP}$ chemotherapy in adult B-cell posttransplant lymphoproliferative disorder (PTLD): the prospective international multicentre phase
2 PTLD-1 trial. Lancet Oncol. 13, 196-206.

Ugarte-Torres, A., Hoegh-Petersen, M., Liu, Y., Zhou, F., Williamson, T. S., Quinlan, D., et al. (2011). Donor serostatus has an impact on cytomegalovirus-specific immunity, cytomegaloviral disease incidence, and survival in seropositive hematopoietic cell transplant recipients. Biol. Blood Marrow Transplant. 17, 574-585.

Uhlin, M., Okas, M., Gertow, J., Uzunel, M., Brismar, T. B., and Mattsson, J. (2010). A novel haplo-identical adoptive CTL therapy as a treatment for EBV-associated lymphoma after stem cell transplantation. Cancer Immunol. Immunother. 59, 473-477. van Esser, J. W., Niesters, H. G., van der Holt, B., Meijer, E., Osterhaus, A. D., Gratama, J. W., et al. (2002). Prevention of Epstein-Barr viruslymphoproliferative disease by molecular monitoring and preemptive rituximab in high-risk patients after allogeneic stem cell transplantation. Blood 99, 4364-4369.

Walls, T., Shankar, A. G., and Shingadia, D. (2003). Adenovirus: an increasingly important pathogen in paediatric bone marrow transplant patients. Lancet Infect. Dis. 3, 79-86.

Walter, E. A., Greenberg, P. D., Gilbert, M. J., Finch, R. J., Watanabe, K. S., Thomas, E. D., et al. (1995). Reconstitution of cellular immunity against cytomegalovirus in recipients of allogeneic bone marrow by transfer of T-cell clones from the donor. N. Engl. J. Med. 333, 1038-1044.

Watcharananan, S. P., Kiertiburanakul, S., Piyatuctsanawong, W., Anurathapan, U., Sungkanuparph, S., Pakakasama, S., et al. (2010). Cytomegalovirus, adenovirus, and polyomavirus co-infection among pediatric recipients of allogeneic stem cell transplantation: characteristics and outcome. Pediatr. Transplant. 14, 675-681.

Wilkie, G. M., Taylor, C., Jones, M. M., Burns, D. M., Turner, M., Kilpatrick, D., et al. (2004). Establishment and characterization of a bank of cytotoxic $\mathrm{T}$ lymphocytes for immunotherapy of epstein-barr virus-associated diseases. J. Immunother. 27, 309-316.

Wills, M. R., Carmichael, A. J., Mynard, K., Jin, X., Weekes, M. P., Plachter, B., et al. (1996). The human cytotoxic T-lymphocyte (CTL) response to cytomegalovirus is dominated by structural protein pp65, frequency, specificity, and T-cell receptor usage of pp65-specific CTL. J. Virol. 70, 7569-7579.

Yao, J., Bechter, C., Wiesneth, M., Harter, G., Gotz, M., Germeroth, L., et al. (2008). Multimer staining of cytomegalovirus phosphoprotein 65-specific $\mathrm{T}$ cells for diagnosis and therapeutic purposes: a comparative study. Clin. Infect. Dis. 46, e96-e105. Zandvliet, M. L., Falkenburg, J. H., van Liempt, E., Veltrop-Duits, L. A., Lankester, A. C., Kalpoe, J. S., et al. (2010). Combined CD8+ and $\mathrm{CD} 4+$ adenovirus hexon-specific $\mathrm{T}$ cells associated with viral clearance after stem cell transplantation as treatment for adenovirus infection. Haematologica 95, 1943-1951.

Zandvliet, M. L., van Liempt, E. Jedema, I., Veltrop-Duits, L. A., Willemze, R., Guchelaar, H. J., et al. (2011). Co-ordinated isolation of $\mathrm{CD} 8(+)$ and $\mathrm{CD} 4(+) \mathrm{T}$ cells recognizing a broad repertoire of cytomegalovirus pp65 and IE1 epitopes for highly specific adoptive immunotherapy. Cytotherapy 12, 933-944.

Zhou, W., Longmate, J., Lacey, S. F., Palmer, J. M., Gallez-Hawkins, G., Thao, L., et al. (2009). Impact of donor CMV status on viral infection and reconstitution of multifunction CMV-specific $\mathrm{T}$ cells in CMV-positive transplant recipients. Blood 113, 6465-6476.

Conflict of Interest Statement: The authors declare that the research was conducted in the absence of any commercial or financial relationships that could be construed as a potential conflict of interest.

Received: 19 October 2012; accepted: 17 December 2012; published online: 28 January 2013.

Citation: Eiz-Vesper B, Maecker-Kolhoff $B$ and Blasczyk R (2013) Adoptive Tcell immunotherapy from third-party donors: characterization of donors and set up of a T-cell donor registry. Front. Immun. 3:410. doi: 10.3389/fimmu. 2012.00410

This article was submitted to Frontiers in Alloimmunity and Transplantation, a specialty of Frontiers in Immunology. Copyright () 2013 Eiz-Vesper, MaeckerKolhoff and Blasczyk. This is an openaccess article distributed under the terms of the Creative Commons Attribution License, which permits use, distribution and reproduction in other forums, provided the original authors and source are credited and subject to any copyright notices concerning any third-party graphics etc. 